\begin{tabular}{|c|c|}
\hline \multirow{3}{*}{ DOSSIER } & JOURNALISM IN NEW \\
\hline & CLOTHES: \\
\hline & $\begin{array}{l}\text { Considerations on the identity and } \\
\text { professional practice based on Prêmio } \\
\text { Imprensa Embratel }\end{array}$ \\
\hline $\begin{array}{r}\text { SBPjor / Associação } \\
\text { Brasileira de } \\
\text { Pesquisadores em } \\
\text { Jornalismo }\end{array}$ & $\begin{array}{l}\text { MILTON JULIO FACCIN } \\
\text { Universidade Estácio de Sá } \\
\text { SORAYA VENEGAS FERREIRA } \\
\text { Universidade Estácio de Sá }\end{array}$ \\
\hline
\end{tabular}

ABSTRACT - This article addresses some ideas about current journalistic practices and their consequent interventions in redefining the professional ethos of the business environment in the Brazilian press. As in other professions, the journalistic identity results from a network of social representations that, through a set of concepts, techniques and procedures, reproduces and is produced by everyday practices originated in their field. Among these practices are the awards granted to professionals. Certain awards have become so relevant that they are taken as benchmarks for good professional practice and, concomitantly, evidence of journalistic practice paradigms. This is the case of Prêmio Imprensa Embratel, chosen here as the object of study. The choice is guided not only by the sponsoring company, but also by its connection with the associations. With different aspects from the most traditional prize in the field, Prêmio Esso de Jornalismo, Prêmio Imprensa Embratel emphasizes the ramifications of the reportage practice, through the categories that do not concern solely on the content of the coverages, but also seek recognition as a kind of prize made by and for journalists.

Keywords: Journalistic Field. Habitus. Prêmio Imprensa Embratel. Professional Identity

\title{
JORNALISMO DE ROUPA NOVA: Considerações sobre a identidade e a prática profissional a partir do Prêmio Imprensa Embratel
}

RESUMO - O presente artigo arregimenta algumas reflexões acerca das práticas jornalísticas atuais e suas consequentes intervenções na redefinição do ethos profissional no ambiente empresarial da imprensa brasileira. Como em outras categorias profissionais, a identidade jornalística resulta de uma rede de representações sociais que, por meio de um conjunto de conceitos, técnicas e procedimentos, reproduz e é produzida pelas práticas cotidianas originadas em seu campo. Entre essas práticas estão as premiações concedidas aos profissionais da área. Nesse sentido, certos prêmios tornaram-se tão relevantes, que tendem a ser tomados como referência de bom exercício profissional e, concomitantemente, evidenciam paradigmas da prática jornalística. Esse é o caso do Prêmio Imprensa Embratel, escolhido aqui como objeto de estudo. Para tanto, a escolha norteia-se não apenas pela empresa patrocinadora, mas também por sua ligação com as entidades de classe. Com aspectos diferentes do prêmio mais tradicional do campo - o Prêmio Esso de Jornalismo - o Prêmio Imprensa Embratel enfatiza os desdobramentos da prática da reportagem, com base nas categorias que não visam unicamente ao conteúdo das coberturas, além de buscar o reconhecimento como um tipo de prêmio feito pelos e para os jornalistas.

Palavras-chave: Campo Jornalístico. Habitus. Prêmio Imprensa Embratel. Identidade Profissional. 


\section{PERIODISMO CON ROPA NUEVA: consideraciones sobre la identidad y la práctica profesional a partir del Premio de Prensa Embratel}

RESUMEN - Este artículo presenta algunas reflexiones sobre las prácticas periodísticas actuales y sus consiguientes intervenciones en la redefinición del etos profesional en el entorno empresarial de la prensa brasileña. Al igual que en otras profesiones, la identidad periodística resulta de una red de representaciones sociales que, mediante un conjunto de conceptos, técnicas y procedimientos, reproduce las prácticas cotidianas originadas en su campo y es producida por ellas. Entre estas prácticas están los premios otorgados a los profesionales. Ciertos premios han llegado a ser tan relevantes que tienden a ser tomados como referencia de la buena práctica profesional y, simultáneamente, evidencian paradigmas de la práctica periodística. Este es el caso del Premio de Prensa Embratel, elegido aquí como objeto de estudio. La elección viene determinada no sólo por la empresa patrocinadora, sino también por su relación con las entidades de clase. El Premio de Prensa Embratel, diferente en muchos aspectos del Premio Esso de Periodismo, el más tradicional del área, enfatiza los desdoblamientos de la práctica del reportaje, por medio de categorías que no se refieren exclusivamente al contenido de las coberturas, además de buscar el reconocimiento como una forma de premio hecho por y para periodistas.

Palabras clave: Campo periodístico. Habitus. Premio de Prensa Embratel. Identidad profesional.

\section{A THEORETICAL VIEW OF AWARDS}

Journalistic activity is formed by a set of techniques, practices and norms that guide professionals in informing society about matters of public interest, through a report based on facts and the greatest possible sense of objectivity. Writing manuals, renowned professionals and Journalism courses are examples of how to ensure cohesion in this activity around criteria of its own, as postulated by Nelson Traquina (2008), who theorizes that journalism has a "mode of seeing, speaking and acting". So every day, the media offers an orchestrated sequence of images, words and hundreds of graphic signs, imagery or sound over piles of paper, on the radio or television. By mobilizing professionals, machines, ethical standards, ethical conduct and production routines, journalists strive to perform their activities based on parameters that the field itself offers from a collectively constructed ethos that materializes in the habitus of the professional identity. This practice is able to generate competition that, in some cases, aims to earn prizes awarded to prominent journalists in the professional category.

For those who decide to compete, the requirement of suitability to the standards of the coveted awards is implicit in their works. Once achieved, this practice becomes a good example of journalistic behavior, as if it were a magic formula to get the first place. From a symbolic point of view, peer recognition is the best medal that a journalist can receive. On the issue of awards, it is worth remembering what the philosopher Antonio Vieira - priest of the Society of Jesus and influential Portuguese missionary in Brazil - prophesied in his book Sermon of the Visitation of 
Our Lady, published in the late seventeenth century:

It's necessary to have prizes for soldiers there, and the awards must be achieved through the gates of worthiness: take into consideration the shed blood, and not only the inherited; take into consideration the intrinsic value, not only the financial value, because after the financial value was introduced in the world, military honors started being sold, militia became into robbery, and soldiers go to war to get money to buy things, not to achieve feats (VIEIRA, $1998 \mathrm{~s} / \mathrm{p}$ ).

The words of Antonio Vieira allow us to think about the role of awards for journalists from different areas by their professional performance. That is why the prizes awarded may function as benchmarks, generating and/or reinforcing certain practices which are gradually incorporated into the habitus (in the sense employed by Pierre Bourdieu) and serve as paradigms of the interpretative journalism community (Traquina, 2008). Based on this perception, there is the hypothesis that, at present, some awards makes their winners more noticeable because they are part of the capital and are considered relevant to a benchmark for journalistic practice. At the same time, awards reveal new paradigms of journalistic practice due to at least three factors: 1) the nature of the social field, 2) a logic operation, and 3) its capacity to help professional stand out among their peers.

In the first case, depending on the characteristics of each award, its categories and judging criteria, beyond the event itself, awards play a coercive role in the field. This happens to the extent that is appropriate for the interpretative journalism community as parameters that guide professional practice of journalistic essays, like the steps to follow to achieve the ultimate goal, which is winning the prize. At the same time that awards provide the crowning of a practice, they also indicate how the conduct of professionals should be in their daily practice of selecting, collecting, calculating, processing and distributing information, which is gradually incorporated to what Pierre Bourdieu called habitus of a professional identity as a social field. That means a way of perceiving and thinking that underlies individual subjectivities and will be reflected in the classification systems of professional activity on what is legitimate and illegitimate. In Journalism, that would be, for example, the parameters of what is considered true or false, what is newsworthy or not, what is a fact and what is an opinion, and so on.

At this point, the notion of social field of Bourdieu is essential to understand how professionals are introduced in the journalistic interpretative community, and gradually incorporate their habitus, where "(...) the positions of the agents are a priori settled" (Bourdieu, 
1990, p. 156 ). The author's concepts highlight the effective relations of the agents in the field, unlike the functionalist views that shield their transformative role of reality. Briefly, Bourdieu identifies a social field as "an area where objective relations take place", in which agents (who are the subjects invested with a habitus), struggle to establish who is entitled to speak and what is legitimate to be spoken. The social space in which the author refers is seized as an "organized group" , whereby the positions of social actors define themselves in relation to each other, forming thus a "system of positions" which is defined by their position, as the cardinal points are defined in relation to their opposites (Bourdieu, 1983, p. 21).

This aspect refers to the idea that journalism is reproduced within the field, with relative independence, whose production structure is driven by an interdependent, internal dynamics and confrontations (marketing, political, communicative, and discursive) and determines the position of the vehicle and actors of communication in relation to this structure. The social field is perceived as a "microcosm" that has its own laws, which will determine the right to enter, the value of the prizes to obtain, as well as the limits of subversion, through a "tacit agreement" about the rules of the game among its players (Bourdieu, 1997, p. 14). So, the journalistic field is an institutionalized situation in which its agents (journalists, distributors, advertisers, shareholders) develop their actions as activities governed by rules and conventions valid for each field, becoming daily work routines. Thus, the professionals who are part of the journalistic interpretative community form a contingent that organizes its activity guided by a routine that revolves not only around the production of news, but also on perception schemes of its participants, based on the habitus of professional identity.

The second point that supports the hypothesis that the awards become paradigms of journalism is based on the understanding that the aforementioned productive logic of the field is created by competitive struggle. Despite the legacy of Cartesian rationalism and scientific positivism in the interpretations of these activities, to consider the existence of a functioning logic of the journalistic field originated from relationships among peers is to recognize that every journalist is a subject historically and ideologically situated in a social context and positioned in a distinctive way in the social space of his/her occupation. By the words of Bourdieu, the social field is the "space for relations", the "locus where a competitive struggle among stakeholders happens. This struggle is about specific interests that characterize the area in question 
(...) and not the result of the actions of individual agents" (Bourdieu, 1997, p. 19).

Fausto Neto (1991, p. 23) believes that it is necessary to stop considering journalism as an intermediary device, articulation and support of something that is external to it, placing it as if it was out of the context of communication, reducing it to merely techniques, "recipes" provided by writing manuals or "tricks" obtained throughout the performance of journalistic practice. It is assumed that the mere mobilization of special techniques, if used properly, is enough for the proper exercise of "doing journalism". It is unknown that journalists are served by those - language, codes and rules of the languages field - to, in the work of enunciation, produce speeches. (...) Forgetting facts and enslaving rules, journalists assume they exercise the called objectivity (FAUSTO NETO, 1994, p. 41).

Thus, it is possible to postulate that competitive struggle is institutionalized in a situation in which the agents mentioned above develop their actions as activities governed by rules that apply specifically to each field. The greater or lesser degree of participation of these agents implies the possession and use, to some extent, of various types of resources, which Bourdieu called "capital"1. It is around this capital that the competitive struggle of the agents occurs, as the author explains: "The agents that occupy the first pole (dominant) are precisely those that have a maximum capital. In return, those who are in the dominated pole are defined by the absence or scarcity of capital " (1983, p. 37).

The awards given to journalists could be part of "symbolic capital" which, in the opinion of the author, includes the accumulated merits, prestige and recognition associated with the person or position. Thus, the competitive struggle around the appropriation of this capital would be irreducible to the extent that its agents demonstrated greater or lesser interest to fight for it (Bourdieu, 1994, p. 5). Here it is also important that each distinctive type of award has intrinsically compared to others. In Brazil, for example, the highlight is the Prêmio Esso de Jornalismo, followed more recently by Prêmio Imprensa Embratel.

The consequence of this symbolic capital is credibility. It takes us to the third aspect of the working hypothesis. The nature of journalism is to make someone believe something. Vehicles of communication, for example, believe that they know the world and the needs of the audience - that makes them believe, in turn, that the audience needs them to know things. In exchange, they offer news, an authentic perishable good. Its logic production needs to be approved by the market through the 
direct sanction of spectators/readers, or indirect audience analysis, leaving the journalists more likely to adopt the criteria of the market in the production or evaluation of products and occupy a higher position in an organ most directly dependent on the market. This also involves attracting customers, competing for priority of the newest news (the scoop), and it becomes more evident the closer the journalistic field is of the commercial hub. Thus, included in the structure and mechanisms of the field, the competition for priority and exclusivity attracts and favors agents with professional provisions who tend to put all the journalistic practice under the sign of speed and constant renewal, forcing them to live and think in everyday life and to take the relevance of information into consideration (BOURDIEU, 1994, p. 106-108).

There would be constant vigilance over the activities of competitors in order to take advantage of their failures, avoiding their mistakes and guiding similar matters, both to prevent competitors from having them as well as to actually want to have them. This is why Bourdieu will say that competition, far from automatically generating originality and diversity, tends often to encourage uniformity of supply (Bourdieu, 1994, p. 108-109). The imperative of credibility is linked to the ability to accumulate capital, both by professionals and by newspaper companies (for the audience to express their preferences, but also by peers, those who excel in honors, leadership positions, experience, competence and accumulation of awards).

Journalistic awards would then aim to accumulate capital throughout recognition. They are not mere awards; they imply the journalist's adherence to a daily practice in order to conquer it, beyond the financial value, typical of a reward. In the former case, we have the idea of the economic value, in the latter, the value itself. A reward is associated with the fulfillment of a given task and its opposite would be the punishment. In this sense, people would do things, or cease to do them, in order to get rewards. That is why they must trained or conditioned. Rather, the need for recognition is the nature of human beings. It is nice to be recognized. It is good to be respected. Recognition would then guarantee an authorized practice, mediated and constructed by the discursive formation of journalism, in the Foucault's sense ${ }^{2}$ (FOUCAULT, 1998), and, therefore, potentially changing professional paradigms.

\section{JOURNALISM AWARDS ARE SPREADING}

In the history of mankind, we find several examples of awards 
associated with recognition. The gladiators of the ancient Roman Empire, for example, as slaves, were forced to fight for their lives in an arena to entertain the general audience, who would decide whether the loser should die or not. The fighters were prisoners of war, slaves and serious offenders, who fought with animals or against each other. They had trained in specialized schools to fight in the arena, received special treatment in the breaks. That means that being a gladiator was better than being a simple slave, and the gladiator could also be recognized by the audience. There are numerous journalistic awards worldwide. They are so many that it is almost impossible to make a minimally representative mapping, as Alberto Dines analyzes in an article published in 2001 at the Brazilian specialized vehicle Observatório da Imprensa: "The number of national awards for journalism is huge. It is hard to pinpoint because there is no control over their criteria, procedures and even results. The Fenaj ${ }^{3}$ or $A B I$ naturally entitled to organize this flood, do not do it" (DINES, 2002, s/p).

One of the worldwide famous awards is the Pulitzer Prize, awarded to professionals who perform work of excellence in journalism, literature and music in the United States. Divided into 21 categories, it was created in 1917 by Columbia University in New York, from the desire of Joseph Pulitzer, who left a sum of money to fund the award, before his death. Despite having several categories, each edition the organizers award a winner in the category of public service journalism, which is not an individual but a press vehicle. The other winners receive cash prizes and certificates. Only articles and photographs published in the U.S. press.

Pereira (2005) as cited in Dias (2008, p.166):

The awards for journalists seem to operate as a positive incentive to professional writers (...) operate with the imagery of the journalist in his capacity as a promoter of 'good news' and a messenger of change (...) are also a way to give a certificate of "good" or "bad" journalist, as a kind of seal of quality to the professional.

In Brazil, the equivalent of the Pulitzer Prize is Prêmio Esso de Jornalismo, which shares space with a variety of other awards. In general, different awards can be classified in two ways. On one hand, those who are distinguished by the nature of the award, with its goals and values of journalistic practice in evidence. On the other hand, the prizes can be analyzed by how they were created, the bond with the promoter that usually is who holds the coordination of each edition. In the latter case, the awards link the name of the sponsoring entity to the contest and 
seek to make its mark in the value (and concept) of what they want as excellence in journalism. Most often, the award serves as a marketing strategy that creates visibility and adds value to the brand. In other rare cases, they work as natural unfolding of the promoting activity and add value to the category. Dines criticizes the first type of award:

\begin{abstract}
Any marketing student knows the feature: if the client does not want to spend much, but wants to make his brand more visible, and have more media exposure, he creates a journalism contest with his name in the title. Vehicles open spaces before, during and after the awards, seduced by the opportunity of self-promotion. (DINES, 2007. $\mathrm{n} / \mathrm{p}$ )
\end{abstract}

From a quick survey on the Associação Nacional dos Jornais (ANJ), Associação Brasileira de Imprensa (ABI) and Federação Nacional dos Jornalistas (Fenaj) websites, it is possible to identify at least five types of award promoters: private business groups, third-party nongovernmental organizations, professional class associations, academic and research centers and communications companies. Note, therefore, that the awards come from different sectors of society. Perhaps because of the very fact that journalism covers all areas of human intelligence and sensitivity and enables social visibility.

In relation to its nature, awards create different categories to account for the diversity of narrative forms that journalistic practice takes. In this case, the categories of each of these awards reflect a certain view of the field and professional competence. Such categories can be grouped into three major groups, which are: journalistic practices related to broadcast media productions (radio, television, press, website, blog), subject matter (sports, cultural, scientific, environmental, economic, child, etc.) and the way information is "formatted" (graphic design, photography, reportage film, first page, television news). There are also awards to honor a renowned journalist who is relevant to the development of the profession, giving their name to a specific category.

In general, awards are national, but they have regional divisions. The jury usually consists of important people in the journalistic field (usually from the market), so evaluation is performed by peers. Since each edition includes several categories of awards, there is also a "grand prize", which may or may not have the name of a journalist. In Embratel, for example, there is Grande Prêmio Barbosa Lima Sobrinho and Troféu Tim Lopes ${ }^{4}$, the latter one for the category of Investigative Journalism. Some awards, due to their presence in earlier editions, their specific business interests, or even because of financial constraints, offer one 
single prize. There are also certain awards that are seasonal or have had one or two editions only, apparently working as a "marketing ploy".

While there are many awards, the same does not occur with studies on those awards. According to a survey conducted in 2008 by Robson Dias (2008) in physical and virtual collections of 18 Brazilian research centers $^{5}$, there is no significant presence of scientific publications on the subject, including graduate program research. A free survey using websites proves this perception, because even today there are rare occurrences. In general, the few researches about awards emphasize the management of enterprises, opportunity recognition, or meritocracy ${ }^{6}$. That means the studies do not include a sociological or symbolic debate about the awards, they just point to the analysis of the award itself, its history and importance in the context of competition. However, there are specific studies on the Prêmio Esso de Jornalismo, Imprensa Embratel and some others ${ }^{7}$.

\section{JOURNALISM IN NEW CLOTHES}

Each award creates new guidelines for implicit journalistic practice and is defined as they point to different professional identities. The Prêmio Imprensa Embratel, for example, in its 14 years of existence, has had more than eight thousand nominees. At the time of its creation, according to the contest website ${ }^{8}$, it was supported by different institutions based in Rio de Janeiro, among them trade unions, associations of media professionals and opinion makers. The goal was to turn this contest into a broader project nationwide, which would be able to mobilize all the media throughout the country. It also sought to create a "dynamic and up-to-date" award, contemplating journalistic work which fitted the "new social, economic and cultural life of the Brazilian people", while it was "able to stimulate and disseminate collective debate on relevant themes such as social inclusion, environmental awareness and redemption of our cultural values"9.

Note that the award is linked to a telecommunications company present in all regions of the country and it also carries the trait of what being Brazilian really means, although it has been through deep transformations in the last 15 years. Embratel is a publicly traded company, founded in 1965, in Rio de Janeiro, as one arm of the state long-distance company Telebras. It was privatized in 1998 by the former Brazilian president Fernando Henrique Cardoso. After being part of several foreign groups, it has belonged to America Movil since 2011, 
owned by Mexican businessman Carlos Slim. It is not surprising that the first edition of Prêmio Imprensa Embratel, in 1999, has had only one category, in telecommunications. The winning report was written by Nice de Paula, journalist from the newspaper O Dia (RJ). Its title was Telebras - Tomorrow, the world's largest auction.

Even though in its origin the award has been designed from one category, it became stronger in the $21^{\text {st }}$ century when it advertised itself as an award in constant transformation, creating new categories and extinguishing others. The category of Television Journalism, for instance, created on the second edition, has already showed the concern in contemplating various forms of journalistic practice. The inclusion of the word "report" in almost all categories indicates that the competition initially considers almost all activity in journalism an activity of reporting. The image, for example, is now considered in the categories Photography Reportage and Film Reportage. This conception of the activity may award series of articles, essays and photographic sequences and the fact that a TV report has already reached the Great Award.

In its website, Prêmio Imprensa Embratel announces itself using the following words: "In each edition, the prize is updated, following the evolution of media and adapting itself to the new challenges of Brazilian journalism"10. By observing the evolution of the award categories organized for the purpose of analysis of this research -, it is possible to see how they follow the development of journalistic practice, broadening its scope, as predicted in their website, in an attempt to be adapted to the "new reality of the country and the new challenges of Brazilian journalism"ll. After enrolling in the category, the competing works undergo successive journalistic sieves, involving currently checking if the author of the report is a journalist with professional registration and if the report was published in a media vehicle, for example. This highlight was possibly motivated because a degree is no longer required to work as a professional journalist, as well as due to some protests over the decision of the jury in 2006, when it awarded Honorable Mention to the work "Hawk - Boys trafficking", televised by TV Globo. The application was accepted and the work was considered hours concours, since there were no reporters involved in it. It was performed by the rapper MV Bill and Celso Athayde, a businessman. Both directed and Rodrigo Felha and Miguel Vassy filmed the documentary. It was considered that the material represented "an exhaustive research, editing, script and production ${ }^{12}$.

The trial of the 14th edition, in 2013, like the previous ones, was done in three phases: Preliminary Evaluation, Regional Selection 
and National Trial. The Preliminary Evaluation Committee is composed by a general coordinator and seven members (two representatives of associations and five indicated by the sponsor). This committee selects about ten reports by category. At this phase, it is possible to recommend the relocation of a particular report to another category not indicated in the description if the board finds that it does not fit in the category indicated by the author. In the regional selection turn, there is a new committee, consisting of twelve journalists from all regions of the country. They are indicated by the organizers and the sponsor. The committee makes the evaluation of regional reports, assigning grades to the works selected by the Committee for Preliminary Evaluation. Based on the score obtained, at least three reports in each region are forwarded to the National Judging Committee.

The National Judging Committee consists of twelve members, chosen from renowned media professionals. Their names must be approved by the sponsor, organizers and organizations that support the project. Among the most frequently chosen, we can find teachers, journalists and writers like Arnaldo Niskier and Zuenir Ventura, who are in the jury since the first edition, the chairman of the Associação dos Repórteres Fotográficos e Cinematográficos do Rio de Janeiro, Alberto Elias Jacob and former President of the Sindicato dos Jornalistas Profissionais do Município do Rio de Janeiro, Janice Caetano. The committee is chaired by one of its members, chosen at the initial meeting. He has the power to decide in the event of a tie in any of the existing categories. Caetano has been president of the jury several times and responsible for breaking ties like the one in 2007, which awarded the photo essay "O começo do fim - efeitos do aquecimento global" - ("The beginning of the end - effects of global warming"), published in the newspaper Jornal do Commercio, from the state of Pernambuco. In his photos, photojournalist Marcos Michael showed "the reality of the drought in Pernambuco, showing the landscape battered by global warming and images of people suffering the cruel consequences of lack of water in the region ${ }^{13 . "}$ With this decision, there was a breaking point in the trend of valuing only images of violence in category Photographic Report.

The National Jury grades each work and each category. Then, the winners are announced considering their average score. In addition, the committee elects the report for the Great Award Barbosa Lima Sobrinho and may disqualify jobs that are not suited to the purpose of the contest. The meeting of this commission, unlike the previous phases, is held inperson to solve questions and indicate the great prize winner, who will 
not be the winner of a specific category anymore. In the first editions of the contest, there were writers and advertising professionals in the jury, fact that has always been highlighted in the books that tell the history of the award. Unlike the Prêmio Esso, which has a different commission to analyze photos, for the Prêmio Embratel, the jury is the same for all categories. However, following a system established by Prêmio Esso, the Embratel computerized their procedures, such as registration, analysis and dissemination of trial results ${ }^{14}$.

In its 14 editions, Prêmio Imprensa Embratel has created 20 award categories, in addition to the regional categories and the Grande Prêmio Barbosa Lima Sobrinho. Except for the first year of the competition - which featured only the category Telecommunications, lasting only one edition - six categories were short lived (Reporting on the Internet, Newspaper and Magazine Reporting, Report of Foreign Correspondent, Telecommunications - Specialized Vehicles, Telecommunication - Nonspecialized Vehicles, Information Technology, Communication and Multimedia in Specialized Vehicle, Information Technology, Communication and Multimedia in Non-specialized Vehicle), eight were created gradually over the years (Reporting Newspaper, Magazine and Internet, Investigative Journalism - Tim Lopes Prize, Social Responsibility - Instituto Embratel Prize, Cultural Reporting, Feature Film, Economic Report, Report on Education, Information Technology, Communication and Multimedia), four are from the second edition (Sports Report, Photographic Report, TV Report, Radio Report).

In the history of the award, it is clear that there is a fluidity of categories, possibly reflecting the professional transformations and the proper postmodern paradigm. Some categories no longer exist, such as Report by Foreign Correspondent, and there is a gradual deletion of the word specialization of categories that had this term in their names before, such as Telecommunications - Specialized Vehicles and category Information Technology, Communication and Multimedia in Specialized Vehicles. Despite the overwhelming input of journalism in the world of new technologies of communication and information, the internet has never really been understood/resolved, judging by its irrelevant presence as a category. In 2007, for example, two categories of technology merged into a broader one: Information Technology, Communications and Multimedia. Also in the 2004 edition, the category Internet Report was incorporated into the category Report for Newspapers, Magazines and Internet.

The categories of Prêmio Embratel Imprensa multiply in relation 
to the content of the news eligible for the contest. There is a group of categories that demonstrates the importance of some areas in social life, beside those that prioritize the technique and/or the media profession. They refer to the cultural, economic and educational spheres, named: Cultural Report, Economic Report and Report on Education. Thus, the award agrees that journalism should be focused on these aspects of human and social life, not just reporting, but also promoting their development. This slope is explained on the overall goal of the awards, which reads: "(...) to recognize and encourage the production of reports on major national issues (...) representing an effective contribution to social inclusion and sustainable development, helping people become actual citizens and being kind of a realistic and constructive X-ray of Brazil"15.

The recognition of the place of investigative work should occupy in professional practice emerges as a category only after the death of journalist Tim Lopes in Rio de Janeiro, in 2003, initially called Investigative Journalism (Troféu Tim Lopes) and later Investigative Reporting (Troféu Tim Lopes). There is a specific regulation for this category, which provides guidance on the criteria to become eligible to apply for the award. Reports based only on past documents (reports, processes, files) or documents provided by third parties will not be considered as Investigative Reports. The category includes only reports or series, regardless of the subject matter and media where they have been published (newspaper, magazine, radio, television or internet).

That means that the research is not exclusive to just one area, but to all the dimensions of human and social life, provided that they are relevant in a scenario and/or in a regional or national reality. According to the vision of this award, the report should be the result of the research/investigation by the reporter or his team, demanding effort and dedication of its author(s), with fieldwork, whose publication must generate a concrete outcome of the case on its proper sphere of social competence. This can be proved by the terms of the award regulation: "The consistency of the report can also be proved by the outcome of the case: ability to generate investigation - by the police, by the judicial instances or parliament - inquiry, prosecution, judgment, etc ${ }^{16 "}$.

From the point of view of the discourse, the award categories are important because they represent the name of journalistic practice, its recognition, its institutionalization and its autonomy in relation to other practices. They work as a discursive device ${ }^{17}$ classification of journalism, operating a microsphere and replacing a possible generic term that may 
camouflage the different forms of news production and perception schemes of habitus of the journalism professional identity itself. Thus, the category name takes the top of all other forms of statements about journalistic activity. It shall ensure consistency and continuity of the statements in the manner of a presupposition. This is because the name refers to knowledge already built and/or under construction, as far as it constitutes a statement of reference that is in relation to other journalistic utterances.

\section{CONCLUSION}

Among the various awards that focus on the field of journalism, Prêmio Esso de Jornalismo and Prêmio Imprensa Embratel are prominent in the Brazilian scene. They are driven by a logic operation that, among other factors, contributes to the visibility and recognition of certain journalistic practices. The first - Prêmio Esso de Jornalismo - is recognized as a place of tradition, with its 50-year history, while the second - Prêmio Imprensa Embratel -- on aspects of enunciation, comes in line with the current changes in the field of journalism, which means it is aware of the new practices in the area.

Drawing on this analysis of Prêmio Imprensa Embratel, it is possible to identify that there are conceptual differences, categories divisions and systems of judgment in relation to Prêmio Esso de Jornalismo. However, in a closer look, what is possible to say is that the Prêmio Imprensa Embratel editions, according to the Prêmio Esso, still value the "old journalism" through its awards. They represented here by the sections considered "serious" and "classic", for example, politics, associated with the so-called "mainstream media" and impregnated by the hegemony of Organizações Globo, as well as for vehicles of communication based on the Brazilian regions with the highest population and industrial rates, particularly the states of Rio de Janeiro and São Paulo. Staffed by professionals working in the newspaper market of the mainstream press, the jury tends to reaffirm the ethos of the area in this case.

An example of this scenario is the observation of the results of the Grande Prêmio Barbosa Lima Sobrinho. In its thirteen editions, Organizações Globo won eight editions, six awards for Rede Globo, one for the newspaper $O$ Globo and another for Revista Época. The other winners were the newspaper O Estado de São Paulo (two editions); Correio Braziliense, from DF (Brazilian District Capital), the magazine 
Isto É and TV Cultura, both from São Paulo (in one edition, each one). Among these, only Correio Braziliense does not have its headquarters in Rio de Janeiro or São Paulo. In relation to the themes, Prêmio Imprensa Embratel, even though it primarily contemplates the section of political issues - remarkable investigative stories on corruption (seven editions), and also for the section of police affairs in two editions ("Dictatorship in the favelas" and "Escaping Vila Cruzeiro"). Other topics include wider issues such as hunger (two editions), the daily routine of indigenous populations and fuel adulteration (one edition each one). The awarded articles usually convey the image of a "complaint" or social relevance and originality of the information provided, reinforcing the role of journalists as those who schedule socially relevant discussions.

By observing the texts that present the winners on the official website of the award, it is possible to note that, from the view of the discourse, there is an exhortation to the work of investigative reporting and the need to document the investigation, highlighting the role of social media as a watchdog of the government, as well as a spokesperson of complaints about social conditions that require changes. This can be realized by the use of verbs such as "reveal", "investigate", "show", "bring out", "register", "note" among others in the same semantic field. Thus, one can question whether each edition, new category, or awardwinning theme is just a "new look" to an "old paradigm". It seems to us that it is precisely this "old paradigm" that defines the ethos and the professional habitus, which reconciles us with the theoretical framework presented, and at the same time justifies the metaphor of "new clothes" in journalism. Therefore, it is not necessarily bad. Rather, it can remind us of what defines "good journalism" - teamwork aiming careful, indepth investigation about socially relevant issues that arise based on complaints and sometimes involving "some danger" or difficulty in obtaining the information, which may require the use of hidden cameras and microphones - which was released from 2007 by the code of professional ethics, when all other means of obtaining information had not achieved success.

This point goes back to the stereotypes, especially popularized by the movies related to journalism. The awards seem to appreciate the heroic aspects of the profession, which some authors have called "Clark Kent Syndrome" (Superman). We remark that, in the category Photographic Report, for example, we should speak of the "Peter Parker Syndrome" (Spiderman), as he acts as a photojournalist for the newspaper Daily Bugle while Clark Kent works as a reporter for the Daily 
Planet. Either way, it is evident that awards value the social function of journalism and its power to oversee and to improve social changes. However, we sadly acknowledge that, at least so far, excellence has only been achieved by journalists, typically working in the Brazilian federal capital, Rio de Janeiro or São Paulo, and holders of news production conditions (time, investments, staff, logistical support) that few vehicles of communication can provide to their professionals.

\section{NOTES}

$1 \quad$ There would be three capitals: economic (including property, material and financial), cultural (knowledge, skills and qualifications), and symbolic (accumulated merits, prestige and recognition associated with person or position).

2 Among other considerations, Foucault (1998) is concerned with discourse as an object of power, i.e., with what the subject is allowed to say, the places he occupies in the speech, among other properties. Extending and relating these to Bourdieu's thoughts, speech depends on the relationship of the symbolic force existing in the journalistic field among all those that are involved, including the audience. That is where the complete definition of competence as the right to speak comes from.

3 Fenaj - Federação Nacional dos Jornalistas (National Journalistic Association) and $\mathrm{ABI}$ - Associação Brasileira de Imprensa (Brazilian Press Association).

4 Barbosa Lima Sobrinho was a journalist and the president of $A B I$ Associação Brasileira de Imprensa and Tim Lopes was also a journalist. He was killed by criminals when we has working on a report to TV Globo about drugs and funk.

5 Survey at the virtual collection of USP, Unicamp, UNB, UFF, UFRJ, UFPE, UMESP, PUCSP, PUC-Campinas, UCB, UFBa, UFSC, UFS, IBICT, CAPES, Universia, Public Domain and physical collection of UNB, UniCEUB, UCB.

6 For example the research: Competências Empreendedoras: um Estudo sobre os Empreendedores Ganhadores do Prêmio TOP Empresarial, by Tania Dias, Paula Nardelli, Alice Vilas Boas.

7 Such as: A agonia da reportagem: das grandes aventuras da imprensa brasileira à crise do mais fascinante dos gêneros jornalísticos: uma análise das matérias vencedoras do Prêmio Esso de Jornalismo, by Magno, Ana Beatriz. Jornalistas que ganharam prêmios (história de vida), by Souza, Maria Isabel Amphilo de. O Prêmio Esso na constituição da identidade profissional do jornalista, by Castilho, Marcio de Souza. Responsabilidade social, pauta no jornalismo contemporâneo: reportagem vencedora do VIII Prêmio Imprensa Embratel apresentada pelo programa Inclusão da TV Senado, by Leda, Erica Lanuck. A influência do prêmio Jornalista Amigo da Criança sobre o profissional de jornalismo: um estudo de caso, by Dias, Robson. O legado de Pulitzer nos tempos do capitalismo financeiro, by 
Koshiyama, Alice Mitika. Vai dar Prêmio: A Valorização da Violência como Tema e do Flagrante como Paradigma nas Fotografias Vencedoras do Prêmio Esso de Jornalismo e do Prêmio Imprensa Embratel, by Ferreira, Soraya Venegas.

8 www.premioimprensaembratel.com.br. Accessed on April 10th 2013 at 1:48 AM.

9 Idem

10 Quote presenting previous awards, found in the event's official website: www.premioimprensaembratel.com.br. Accessed on April 10th, 2013 at 1:32 AM .

11 http://www.premioimprensaembratel.com.br/ Accessed on April 11 th, 2013 at 10:58 AM.

12 http://jornalistas.org.br/siteantigo/noticias.php?idn=163. Accessed on March 15th, 2013 at 10:15 AM.

13 http://www.premioimprensaembratel.com.br. Accessed on April 10th, 2001

14 Idem

15 www.premioimprensaembratel.com.br. Accessed on April 11 th, 2013 at 2:19 PM.

16 Idem

17 MOUILLAUD, Maurice. Da forma ao sentido. In: MOUILLAUD, Maurice; PORTO, Sérgio D (orgs). O Jornal, da forma ao sentido. 2.ed. Brasília: Editora Universidade de Brasília, 2002

\section{REFERENCES}

BOURDIEU, Pierre. A economia das trocas simbólicas. São Paulo: Perspectiva, 1992.

Coisas ditas. São Paulo: Brasiliense, 1990.

Questões de Sociologia. Rio de Janeiro: Marco Zero, 1983.

Pierre. Sobre a televisão. Rio de Janeiro: Jorge Zahar. 1997.

. O Campo científico em Sociologia. São Paulo: Ática, 1983.

. Lições de aula. São Paulo: Ática, 1994.

DIAS, Robson. A influência do prêmio Jornalista Amigo da Criança sobre o profissional de jornalismo: um estudo de caso. 2008. Dissertação (Mestrado em Comunicação), Universidade de Brasília, Brasília, 2008.

DINES, Alberto. Prêmios e Galardões. Available at: www. observatoriodaimprensa.com.br, 2002

Jabá institucional, o que esconde atrás dos prêmios de jornalismo. Access data at www.observatoriodaimprensa.com.br, 2007

FAUSTO NETO, Antônio. Comunicação e mídia impressa. São Paulo: Hacker, 1999. 
Mortes em derrapagens. Rio de Janeiro: Rio Fundo, 1991.

A sentença dos mídias. In: Compós. Comunicação, Cultura e Política. São Paulo: Diadorim, 1994

FOUCAULT, Michel. Arqueologia do saber. Rio de Janeiro: Forense Universitária, 1995.

A Ordem do Discurso. 6.ed. São Paulo: Loyola, 1998

MOUILLAUD, Maurice; PORTO, Sérgio D (orgs). O Jornal, da forma ao sentido. 2.ed. Brasília: Editora Universidade de Brasília, 2002

TRAQUINA, Nelson. Teorias do Jornalismo. Volume II. Florianópolis: Insular, 2008

VIEIRA, Antônio. Sermão da Visitação de NossaSenhora. Erechim: Edelbra, 1998. In.: Literatura Brasileira, textos literários em meio eletrônico. Available at: http://www.literaturabrasileira.ufsc.br/_documents/0006-02072.html.

Milton Julio Faccin Graduated in Social Communication/Journalism UFSM/RS, MS and PhD in Communication and Culture from the ECO/UFRJ, Coordinator of Journalism at Campus Tom Jobim - Universidade Estácio de Sá. Email: miltonfaccin@ yahoo.com.br

Soraya Venegas Ferreira Journalist, Master and $\mathrm{PhD}$ in Communication and Culture from ECO/ UFRJ as Postdoctoral Fellow in Journalism theories from PPGCOM-UFF, Coordinator of Journalism at Campus Niterói - Universidade Estácio de Sá. Email: sosovenegas@yahoo.com.br 